\title{
Media Alignment: Information Reproduction Patterns of Middle East Conflict in Indonesian Media
}

\author{
Y Faisol $^{1}$, S Hadi ${ }^{2}$, Reflinaldi ${ }^{3}$, W Rahmat ${ }^{4}$, R Fakhrurrazy ${ }^{5}$ \\ ${ }^{1,2,5}$ UIN Imam Bonjol Padang, ${ }^{3}$ Universitas Andalas, ${ }^{4}$ STKIP PGRI Sumatera Barat \\ \{yufni_faisol@uinib.ac.id ${ }^{1}$, syofyanhadi@uinib.ac.id ${ }^{2}$, naldirefli@gmail.com³ ${ }^{3}$,wahyudi@stkip-pgri- \\ sumbar.ac.id ${ }^{4}$, rifkyazka.rf@gmail.com $\left.{ }^{5}\right\}$
}

\begin{abstract}
This study aims to uncover the information reproduction pattern of Middle East conflict in Indonesian online mass media. The study model is descriptive qualitative model. The data was taken from the reports on Syrian conflict in Indonesian online mass media i.e. Republika, Kompas, and Tempo. In accordance with the orientation of the study, the data must be conducted on the news from January to October 2018. Data were analyzed by using Miles and Huberman stages of qualitative analysis models. The findings of the study indicate that each media from the data source taken has different ways and perspective in reproducing information and news related to the Middle East conflict. Republika tends to take the point of view againts Syrian government, which bring the United States and its allies to be the central of the news. In the other hand, Kompas is departed from the point of view of the Syrian government and allies by dwarfing the United States and its allies in the news. As the third axis, Tempo takes a chronological perspective and highlights many humanitarian issues in the news.
\end{abstract}

Keywords: Information Technology, Online Mass Media, Middle East Conflict

\section{INTRODUCTION}

Derived from the latest development data released by the Press Council, it was found that Indonesia owns 43,300 online mass media that routinely publish news on various lines and existing sectors [1]. This high number is in line with the intensity of public access to online news, where one of the studies conducted by UC Browser stated that 95 percent of Indonesian citizens get news from their smartphones [2]. By relying on internet connection speed, the mass media presents international news features, so that various events that occur in parts of the world can be easily accessed by the public. Middle East Conflict is one of the news accessed by Indonesian readers. The conflict began with the momentum of the Arab Spring as well as various issues of terrorism and other religious radicalism that have attracted world attention over the past few years [3]. The strategic position of several subjected Middle Eastern countries in the world political and economic crossings has sparked the interest of other countries to participate in the turmoil that occurred in the internal sphere, one of which is online mass media. This intervention at a further stage proved the effectiveness in extending the conflict occurred in various countries involved. 
World political issues that dragged the Middle East as a line of state with a strategic position have politically triggered many Western countries to do military aggression in order to seize power [4]. Foreign media have begun to discuss and report on the existences and severity of events in the Middle East. The gas pipeline, which plays an important role in the flow of the economy and world oil trade, has also triggered the passion of Western countries to invade various related countries [5]. Also, the existence of sociocultural issues and prolonged conflicts between religious groups has given some impacts of chaos in many internal lines of various countries [6]. In several studies, there were mentioned that the media have successfully established the Islamic world e.g. in digitalization, social online, contributed to new forms of social, cultural, economic and political capital [9], some media said that the opposition forces sought to make themselves as the potential allies for the foreign interventions who oppose both for Islamic countries and the Syrian government, while others reject the idea of the foreign intervention by starting to invade Islamic countries in the east [4] [10]. The idea is then actualized in various media of creation [17]. These various interests had caused differences in some media in informing one and the same event. Media takes a subjective angle in reporting events according to the values they believe and to the readers' demands [7]. Some values that have become the fundamental ideology adopted have made it impossible for the media to be in the equilibrium of neutrality in delivering the information to their respective readers. The action is politically aimed at legitimizing the power of a party and the oppression of the others [8].

In the context of the events of the Middle East conflict reported by Indonesian media, the politicization appeared in slightly different forms. This condition is happening because of the difficulty for the people in many counties to access the real events in their original material of news that brings not all media can get the real events their main source of information. The majority of the media obtained the information through other media that had previously reported the occurrence of events. Accordingly, this condition is also happened in Indonesia's media that also reproduce news from the existing media e.g. by reprocessing the information obtained from the first source and presenting it back to the reader so that it can be seen as what the Indonesian media views about the news in the Middle East.

\section{RESEARCH METHOD}

This research is a language research into interconnected is language applying various language theory which in common parlance is known as discourse analysis. Language research is included in qualitative descriptive research within the analysis method which is using content analysis method. Content analysis method use Van Dijk's teory with several step, first, from the dimensions of text, social cognition, and the social context that supports one another.

\section{RESULT AND DISCUSSIONS}

\subsection{Van Dijk's Text Dimensions: Media Discourse Analysis}

Discourse can be seen from the dimensions of text, social cognition, and the social context that supports one another. Discourse as a basis for understanding text is very necessary for the language community in communication with complete information [11]. The essence of discourse analysis is to combine these three dimensions into one unit [12]. In the text dimension the structure of the text and discourse strategies are examined which are used to 
confirm a particular theme. At the level of social cognition the discourse production process is examined which involves the individual cognition of the discourse writer. At the level of the social context, the building of discourse is developed in the community.

In the text dimension, Dijk divides discourse into three elements i.e. macro structure, superstructure, and micro structure. Macro structure (thematic) refers to a general description of a text. Devices that are dissected on a macro structure are the themes used by the creator of the text as a Superstructure process (schematic) pointing to the flow from the introduction to the end to form one meaning. Discourse according to Van Dijk [12] has two major schemes: a summary represented through headlines and leads, and a story which is the overall content. Micro structure refers to the local meaning of a text that can be observed from the choice of words, sentences, and styles of language used in the text. [12]

The framework of the Van Dijk text discourse elements can be seen in the following table

\begin{tabular}{ccc}
\hline Discourse Structure & The matter observed & Elements \\
\hline Macro Structures & Thematik & Theme \\
\hline Superstructures & Schematic & Scheme \\
\hline Schematic & $\begin{array}{c}\text { Background, details, } \\
\text { intentions, presuppositions, } \\
\text { nominalization. }\end{array}$ \\
\cline { 2 - 3 } Micro Structures & Syntax & $\begin{array}{c}\text { Sentences, coherence, } \\
\text { pronouns. }\end{array}$ \\
\cline { 2 - 3 } & Stylistic & Lexicon \\
\cline { 2 - 3 } & Rhetorical & Language style, metaphor \\
\hline
\end{tabular}

\subsection{Data Analysis}

News of the American attack on Syria was reported in Inab Baladi on April 14, 2018 with the headlines that tended to be neutral and flat [13]. The Syrian media chose the title in the form of the following sentence:

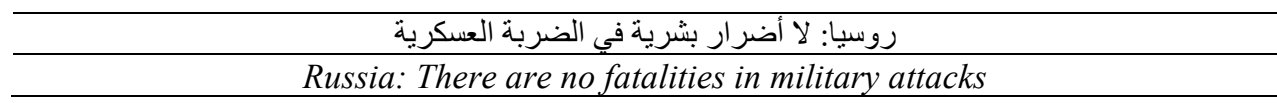

The news then provided information related to the events of the American attack on Syria. It was reported that the attack occurred at dawn in Damascus, a suburb, Homs, as well as a scientific research center in Barza. The attack was carried out to respond to the use of chemical weapons by the Syrian government which killed 60 people in East Ghouta a week earlier.

News of the American attack on Syria on April 14, 2018 were reported by Republika with the title The US Althogether with France and Britain Bombarded Syria (AS Bersama Prancis dan Inggris Gempur Suriah) [14]; by Kompas with the title US and its Allies Firing More than 100 Missiles to Syria (AS dan Sekutunya Tembakkan Lebih dari 100 Misil ke Suriah) [15]; and by Tempo with the title Again, United States and Allies Attacked Syria (Lagi, Amerika Serikat dan Sekutunya Serang Suriah) [16]. The analysis of the tendencies of the three mass media in the news is as follows: 


\subsection{Macro Structures}

The headline of Republika is the following sentence:

AS Bersama Prancis dan Inggris Gempur Suriah

(US Althogether with France and Britain Bombarded Syria)

The headline selection projected a weapon attack launched against Syria which manifested itself through the choice of the Bombarded Syrian clause. The weapons attack was not only carried out by one country's military, but was carried out in cooperation. The attack was fronted by the United States which took France and Britain as allies of attack, as reflected in the US phrase with France and Britain.

The headline of Kompas is the following sentence:

AS dan Sekutunya Tembakkan Lebih dari 100 Misil ke Suriah (US and its Allies Firing More than 100 Missiles to Syria)

The headline selection projected a massive gun shooting launched against Syria. The awesomeness manifested through the phrase 100 Missiles to Syria. The weapons attack was fronted by America and its allies which were not stated concretely. As perpetrators, America and its cooperation partner countries are reflected in the US and Allied phrases.

The headline of Tempo is the following sentence:

Lagi, Amerika Serikat dan Sekutunya Menyerang Suriah

(Again, United States and Allies Attacked Syria)

The headline selection projected the attacks conducted by the US and its allies against Syria. Cooperation in the attack was reflected in the phrases of the United States and its Allies, so that the country was not explicitly mentioned. The attack was described as an attack which was a series and was the continuation of the attacks that had been conducted before. This is reflected in the word Lagi (Again) which contains repetitive meanings. Intentionally, each discourse has a different perspective in compiling news. Republika highlighted the role of France and Britain, which in addition to the United States, was also no less active in the Syrian attack cooperation; Kompas stressed the awesomeness of the attack through the number of 100 missiles fired by the United States and its allies into Syrian territory; Tempo stressed that there had been many attacks carried out by the United States and its allies against Syria. Based on the analysis the headline intentions of each discourse can be seen in the following figure:

\begin{tabular}{cll}
\hline Media & Theme Meeting Point & \multicolumn{1}{c}{ Theme Intention } \\
\hline Republika & & $\begin{array}{l}\text { The existence of France and Britain } \\
\text { as American allies in the event of an } \\
\text { attack. }\end{array}$ \\
\cline { 3 - 4 } Kompas & $\begin{array}{l}\text { America and its allies } \\
\text { attacked Syria }\end{array}$ & $\begin{array}{l}\text { The amount of } 100 \text { missiles fired as } \\
\text { ammunition. }\end{array}$ \\
\cline { 3 - 4 } Tempo & $\begin{array}{l}\text { The attack that was conducted was } \\
\text { not for the first time, but was a series } \\
\text { of attacks that had been conducted } \\
\text { before. }\end{array}$ \\
\hline
\end{tabular}




\subsection{Superstructures}

The news lead-in of Republika is the following sentence:

Presiden Amerika Serikat Donald Trump pada Jum'at (14/4) memerintahkan
pelaksanaan serangan dengan menargetkan fasilitas senjata kimia Presiden Suriah
Bashar Al-Assad.
(US President Donald Trump on Friday (14/4) ordered the implementation of the attack
by targeting Syrian President Bashar Al-Assad's chemical weapons facilities.)

From the data, it appears that the lead-in chosen by Republika to initiate its news structure is the order to attack Syrian chemical weapons facilities by Donald Trump. As the main framing, these leads have an influence on the news orientation that is built through cohesion and coherence between sentences and paragraphs in the news. One of the effects of these leads is the tendency of news stories that globally highlight the significance of Donald Trump's role in attack.

The news lead-in of Kompas is the following sentence:

Dalam serangan pertama ke Suriah, Sabtu (14/4/2018), Amerika Serikat dan sekutunya sudah melepaskan lebih dari 100 misil penjelajahnya.

(In the first attack on Syria on Saturday (4/14/2018), the United States and its allies have released more than 100 explorer missiles.)

From the data, it appears that the lead chosen by Kompas to initiate its news structure is the release of more than 100 explorer missiles by the United States and its allies against Syria. This lead then becomes the basis of the overall news development by the discourse producers. In the story on the news, the 100 explosive missiles launched by America became the starting point for an explanation of the superiority of Russia capable of crippling these missiles through its sophisticated defense system technology.

The news lead-in of Tempo is the following sentence:

Amerika Serikat dan sekutu-sekutunya meluncurkan serangan ke Suriah pada Jumat, 13 April 2018, waktu Amerika. Serangan itu ditujukan Presiden Donald Trump untuk menghukum Presiden Suriah Bashar al-Assad, yang diduga kuat dalang penyerangan senjata kimia di Kota Douma pada 7 April lalu. Penyerangan di Douma tersebut menewaskan lebih dari 40 orang.

(The United States and its allies launched an attack on Syria on Friday, April 13, 2018, US time. The attack was aimed at President Donald Trump to punish Syrian President Bashar al-Assad, who was allegedly the mastermind behind the chemical weapons attack in the city of Douma on April 7. The attack on the Douma killed more than 40 people.)

From the data, it appears that the lead chosen by Tempo to initiate the news was the launch of a US attack which was based on attacks on chemical weapons in Douma City on April 7 by the Syrian government, Bashar Al-Assad. The lead is then a point that has been developed and is much touched on in the news paragraphs.

By paying attention to the lead and story analysis of the three discourses above, analysis of the superstructure can map the reproductive tendencies of each news reflected through the compilation of ideas in sentences and paragraphs. Republika has a tendency to stand out the American leadership in initiating attacks on Syria. Kompas has a tendency to stand out the 
superiority of Russia which can fend off more than 100 American missiles. Tempo has a tendency to show off the significance of the attacks launched by the United States as an effort to protect Syrian civil society and maintain the stability of its own national security.

The different tendencies of each news in the lead and story can be seen in the following figure:

\begin{tabular}{cl}
\hline Media & \multicolumn{1}{c}{ Lead dan Story Intentions } \\
\hline Republika & American leadership in conducting the millitary attacks. \\
\hline Kompas & The power of Russia in fending off the attacks. \\
\hline Tempo & $\begin{array}{l}\text { The manifestation of humanity behind the attacks of the United States } \\
\text { and its allies. }\end{array}$ \\
\hline
\end{tabular}

\subsection{Micro Structures}

Semantically, each discourse puts forward their respective backgrounds in an effort to construct the meaning to the readers'minds. Background status in the meaningful process is very important, because it functions as a tool as well as a medium to lead readers' opinions.

Republika proposes the background in the following sentence:

Perintah itu sebagai tanggapan atas terjadinya serangan gas beracun pekan lalu, yang menewaskan setidaknya 60 orang.

(The order was in response to a toxic gas attack last week, which killed at least 60 people.)

The background of the incident in the form of sadistic chemical weapons attacks conducted by the Syrian government a week earlier was in the first paragraph. The strategy of laying down the background is intended to limit the readers' interpretations not to assume too far about the motives of the attacks conducted by the US. The readers' opinions which are expected to justify and support the US actions as a counter-attack slowly begins to be constructed through the discourse.

Kompas proposes the background in the following sentence:

Kementerian Pertahanan Rusia Mengklaim, sistem pertahanannya berhasil
merontokkan sejumlah misil sekutu.
(The Russian Ministry of Defense Claimed, the defense system managed to knock out a
number of the allied missiles.)

The setting is the claim of the success of the Russian defense system in fending off the United States missile attack placed in the initial paragraph. Setting the background is intended to limit the readers' interpretation of the attack. The discourse constructs the readers' minds that the attack is not effective in the destruction mission that is conducted so that the next paragraph is only additional and not too important.

Tempo proposes the background in the following sentence:

Serangan itu ditujukan Presiden Donald Trump untuk menghukum Presiden Suriah Bashar al-Assad, yang diduga kuat dalang penyerangan senjata kimia di Kota Douma pada 7 April lalu. Penyerangan di Douma tersebut menewaskan lebih dari 40 orang.

(The attack was aimed at President Donald Trump to punish Syrian President Bashar al-Assad, who was allegedly the mastermind behind the chemical weapons attack in the city of Douma on April 7. The attack on the Douma killed more than 40 people.) 
The background for the attack was in the form of punishment to Bashar Al-Assad as the mastermind behind a chemical weapons attack which killed more than 40 civilians who were positioned in the first paragraph. The strategy of positioning the background is an attempt to direct the meaning process in the mind of the reader that the attacks conducted by the United States and its allies were based on sadistic humanitarian events conducted by the Syrian government, in this case Bashar Al-Assad. This background is expected to be able to construct meaning in the readers' minds that the attack is normal and reasonable in order to provide the punishment. Semantically the orientation of each discourse can be seen in an effort to construct meaning in the readers' minds. Through Bashar Al-Assad's cruel image, Republika wants the legitimacy of the reader against the attacks carried out by the United States and its allies against Syria. Kompas wants readers to acknowledge that the attacks launched by America and its allies were ineffective and less sophisticated with Russia's defense system. Tempo wants the readers' judgment that the attacks carried out by the United States and its allies are normal and reasonable.

From the stylistic aspect, the three discourses above have different expressing styles in narrating events. The differences can be seen in the choice of words in the following headlines:

\begin{tabular}{ccll}
\hline Media & Word Choice & \multicolumn{1}{c}{ Meaning Intention } \\
\hline Republika & $\begin{array}{c}\text { Gempur } \\
\text { (Bombarded) }\end{array}$ & Terrible attack; the impact of large-scale damage. \\
\hline Kompas & $\begin{array}{c}\text { Tembakkan } \\
\text { (Firing) }\end{array}$ & Medium attack; smaller scale damage impact. \\
\hline Tempo & $\begin{array}{c}\text { Menyerang } \\
\text { (Attacked) }\end{array}$ & $\begin{array}{l}\text { General meaning; potential damage is not } \\
\text { reflected. }\end{array}$ \\
\hline
\end{tabular}

Republika uses an explosive verb to describe the attacks launched by the United States along with France and Britain against Syria. The use of these verbs is in line with the selected news leads. With the American affirmation orientation as a superpower, the gempur verbs reflect major attacks that can cause severe damage to the target of the attack. Verb gempur also explicitly contains the intention of the meaning of the power of the subject who launches the attack.

On the other hand, Kompas uses firing verbs which have a smaller intensity of meaning than the bombard (gempur) verb. Fire (tembak) verbs have relatively smaller attack intentions and less potential damage to the target of the attack. This is in line with the orientation of the leads built, in which Kompas seeks to emphasize the greatness of Russia in crippling the attacks of the United States and its allies. Meanwhile, Tempo used attack (serang) verb to describe the activities of America and its allies against Syria. The word attack is a general term or parent that covers the word gempur and fired. The use of the term attack symbolizes Tempo's neutrality in seeing the attacks launched by the United States with its allies and prevention conducted by the Russian military. This is in line with the orientation that is built on news leads where Tempo focuses the narrative on motivation and the purpose of attacking the United States and its allies against Syria.

Based on the analysis of the text dimensions in Van Dijk's discourse structure, there are differences in each media in reproducing the issue of the involvement of the United States in the Syrian conflict. These differences make the three media have specific perspectives and emphases, so that they do not fully refer to and are based on the proto media chosen by the researcher. The results of the analysis indicate that Republika has a perspective that tends to 
be gentle towards America - if it does not want to be called sympathetic. This is reflected in the diction, language style, and reporting flow used. In contrast to Republika's view, Kompas actually shows an effort to minimize and minimize the power of the United States. The attacks and attacks carried out by the United States were aired in their usual form and could even be easily defeated by Russian military technology. In line with the perspective and orientation of news related to America, Kompas shows a tendency to bring Russia as a superior power. Unlike Republika and Kompas, Tempo can be referred to as the third axis of media in viewing the Syrian conflict. The involvement of the United States and its allies in the conflict is displayed flat and as is. Tempo regulated the rhythm of the news, so that in one frame, American aggression was displayed as something ordinary and not large in the military world, but on the other hand Tempo acknowledged that humanitarian motives made the US and its allies' aggression to be acceptable and justifiable. That is, Tempo did not broadcast the United States in a superior form through an astounding diction. On the other hand, he also did not negate the existence of logical and rational reasons for the United States and allies to carry out such attacks. Thus, Tempo viewed the involvement of the United States and its allies in the Syrian conflict as a natural thing. This is limited by the existence of rational reasons in the form of humanitarian motives behind the involvement.

\section{CONCLUSIONS}

Based on the data analysis conducted, it was concluded that each media has their own reproductive pattern in the form of framing and perspective in looking at and re-informing the events that occur. Republika tends to reproduce information that describes a contradiction with the Syrian government and its allies, Russia. The consequence of this attitude was the emergence of a tendency to defend against the Americans who clearly stated their hostility towards the Russian government. Kompas tends to reproduce information that describes a pro attitude with the Syrian government and its allies, Russia. The consequence of this attitude is the emergence of tendencies in the form of the destruction of the United States and its allies. In contrast to Republika and Kompas, Tempo tends not to show political alignments. Tempo chose an angle that emphasized more on the series of conflicts that occurred in Syria, without ignoring the facts surrounding the conflict.

\section{REFERENCES}

[1] F. Nashrillah, "Dewan Pers: Ada 43 Ribu Media Online, Hanya 168 yang Profesional," IDN Times, 2018.

[2] A. Mailanto, "95 Persen Pengguna Internet di Indonesia Baca Berita dari Smartphone," okezone.com, 2016.

[3] M. Agastya, "Arab spring: Badai revolusi Timur Tengah yang penuh darah," in IRCiSoD, 2013.

[4] C. M. Blanchard, C. E. Humud, M. B. D. Nikitin, and I. Ave, "Armed Conflict in Syria : Overview and U . S . Response Specialist in Middle Eastern Affairs Analyst in Middle Eastern and African Affairs," Congr. Res. Serv., 2014.

[5] S. Starr, Revolt in Syria: Eye-witness to the Uprising. 2012.

[6] T. Kuncahyono, Musim Semi di Suriah: Anak-anak Penyulut Revolusi. Penerbit Buku Kompas, 2013.

[7] A. Sudibyo, Politik Media dan Pertarungan Wacana. Yogyakarta: LkiS, 2016. 
[8] A. Sobur, Analisis Teks Media: Suatu Pengantar untuk Analisis Wacana, Analisis Semiotik dan Analisis Framing. Bandung: Remaja Rosdakarya, 2006.

[9] D. Yusof, The Muslim World in Cyberia: Prospects for E-Governance and Digital Capacity Building. 2018.

[10] R. Gunaratna, “The Islamic State's Eastward Expansion,” J. Washingt. Q., vol. 39, no. 1, pp. 49-67, 2016.

[11] R. Fitri and W. Rahmat, "Inclusion of Murder News In The Posmetro Padang Daily Newspaper: A Study of Critical Discourse Analysis," Humaniora, vol. 8, no. 4, pp. 311$317,2017$.

[12] T. A. Van Dijk, "Critical Discourse Studies : A Sociocognitive Approach," in Methods of Critical Discourse Analysis, Sage London, 2009.

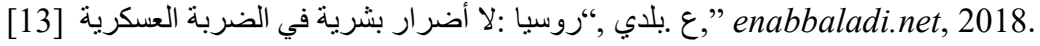

[14] N. Aini, “AS Bersama Prancis dan Inggris Gempur Suriah,” Republika.co.id, 2018.

[15] E. Handoko, “AS dan Sekutunya Tembakkan Lebih Dari 100 Misil ke Suriah," Kompas, 2018.

[16] S. Sekarwati, "Lagi, Amerika Serikat dan Sekutunya Menyerang Suriah," Tempo.co, 2018.

[17] E. K. Maryelliwati, Wahyudi Rahmat, "A Reality of Minangkabau Language and Literature and its Transformation to a Creation of Performance Works.," Jurnal Gramatika Jurnal Penelitian Pendidikan Bahasa dan Sastra Indonesia, vol. 4, no. 1, pp. 62-70, 2018. 